\title{
Monopolization, Mergers, and Markets: A Century Past and the Future
}

\author{
Phillip Areeda $\dagger$
}

Significant anniversaries are often occasions for wholesale generalization, congratulation, or lamentation. My theme is the narrower one of, to borrow a phrase, the law in search of itself. The statutes on which it rests are so general that antitrust law shares a great deal with the common law and is no more to be judged im gross than the law of contracts. Were I nevertheless to generalize grossly, I would point to the large and perhaps increasing number of sensible decisions giving coherence to antitrust policy. Of course, not all decisions fall within that happy category.

I have been asked to discuss the future viability of legal doctrines concerning monopolies, mergers, and markets, and to comment on which of them either promote the public interest or impair it by obstructing the benefits sometimes flowing from a firm's integration or expansion. In this Article, I cannot summarize the several volumes of the Areeda-Turner treatise ${ }^{1}$ or its supplement ${ }^{2}$ that touch on these subjects but must limit my discussion to a few salient monopolization-merger-market doctrines. Although doctrines take their meaning mainly from their applications, I distinguish sensible doctrines from their aberrant applications and consider their viability by examining both unsatisfactory current approaches ripe for change and developing tendencies toward reform.

\section{I \\ MONOPOLIZATION}

Sherman Act section 2 declares simply that monopolization is a crime, along with attempts and conspiracies to monopolize. ${ }^{3}$ It does not define monopoly, explain whether mere monopoly is unlawful in the absence of impropriety, or specify any criteria for determining whether an impropriety has occurred.

\section{A. The Monopoly Concept}

Unless it has a horizontal agreement with its competitors or a verti-

$\dagger$ Langdell Professor of Law, Harvard University. A.B. 1951, LL.B. 1954, Harvard University.

1. P. Areeda \& D. Turner, Antitrust law (1978).

2. P. Areeda \& H. Hovenkamp, Antitrust Law (Supp. 1987).

3. 15 U.S.C. $\& 2$ (1982). 
cal agreement with its customers or suppliers, the individual firm is generally left free by antitrust law to act as it chooses unless it possesses or threatens to achieve monopoly power. Unfortunately, the definition of monopoly power has proved elusive. The cases define it as the power to exclude competition or to control price. ${ }^{4}$ To the economist, market power is the ability to set prices above the level that would prevail in a perfectly competitive market. Although market power, so defined, can be found in many if not most markets, antitrust law cannot feasibly address every deviation from perfect competition; hence courts have never equated the economist's definition of market power with the antitrust notion of monopoly power that would implicate section 2 . While most judges have recognized that "substantial" market power is involved in the statutory concept of monopolization, they have not succeeded in indicating how much power is substantial.

The Justice Department's 1984 Merger Guidelines ${ }^{5}$ reflect the belief that firms unable to raise prices five percent above the competitive level ${ }^{6}$ should not concern the prophylactic antimerger law and, presumably a fortiori, the antimonopoly provision of section 2. Naturally, this figure is arbitrary, and could allow a large sacrifice of consumer welfare in some markets.

Courts applying section 2 have not focused on this question of degree, but have submerged it in the process of market definition, which they usually characterize as a question of fact to be decided by a jury in private treble damage actions. Moreover, the jury usually is instructed to determine whether the defendant has the power "to control price"-a formula that has no meaning until the requisite degree of departure from a competitive price is specified.

Because of this serious deficiency in the identification of actual or prospective market power, present section 2 law requires improvement on three fronts: (1) better descriptions of the degree of price-affecting power necessary to implicate section 2 ; (2) better techniques for assessing power and for defining markets; and (3) better jury instructions and more judicial factfinding.

To be sure, finding monopoly where it does not really exist would

4. See, e.g., United States v. E.I. du Pont de Nemours \& Co., 351 U.S. 377, 391 (1956); Berkey Photo, Inc. v. Eastman Kodak Co., 603 F.2d 263, 272 (2d Cir.) (citing du Pont), cert. denied. 444 U.S. 1093 (1979).

5. U.S. Dep't of Justice Merger Guidelines, 49 Fed. Reg. 26,823 (1984) [hereinafter Merger Guidelines].

6. See id., Statement Accompanying Release of Revised Merger Guidelines, at 26,824. The actual guidelines are unsuitable for determining the presence of monopoly poiver, for they define markets on the basis of a hypothetical five-percent price increase above prevailing prices. They would thus understate the market power of a firm that had already exercised the power to charge prices five percent above the competitive level. 
not be a serious matter if the substantive rules governing actual or prospective monopolists were such that few suits would be brought or succeed in the absence of substantially anticompetitive conduct. But we can have little confidence that section 2 works so beneficently.

\section{B. The Element of Impropriety}

Should the antitrust laws do something about a monopoly when the monopolist has not engaged in any impropriety? Although there would then be no impropriety to enjoin or punish, an equity court might restructure the monopoly, force the licensing of its patents, or take other steps to create new competition. I have elsewhere argued the case for doing so, which depends upon a belief that courts (1) are capable of confining such a remedy to those few cases of persistent monopoly where judicial intervention would clearly improve economic performance substantially, and (2) deny all criminal or damage relief, notwithstanding the finding of a section 2 violation as a predicate for any relief. ${ }^{7}$ On the other hand, one may doubt that these conditions could be satisfied, fear that punishing the successful competitor who achieved monopoly blamelessly would chill the incentives for vigorous competition, and hope that free market forces (if not obstructed by anticompetitive practices) will correct most if not all monopolies.

As the Court put it in the 1911 case of Standard Oil Co. v. United States, ${ }^{8}$ the statute does not forbid "mere monopoly in the concrete." United States v. Aluminum Co. of America ${ }^{10}$ and United States v. Griffith $^{11}$ might be interpreted otherwise. Alcoa professed to condemn a monopoly because it had expanded output (which was not shown to be other than procompetitive), and Griffith indicated that a monopolist could violate section 2 if he had a purpose or intent to monopolize not objectively manifested in any impropriety. Nevertheless, in United States v. Grinnell Corp. ${ }^{12}$ the Supreme Court stated the prevailing formula as follows:

The offense of monopoly . . . has two elements: (1) the possession of monopoly power in the relevant market and (2) the willful acquisition or maintenance of that power as distinguished from growth or development as a consequence of a superior product, business acumen, or historic accident. $^{13}$

Although the Court continued to use the "willful acquisition" language,

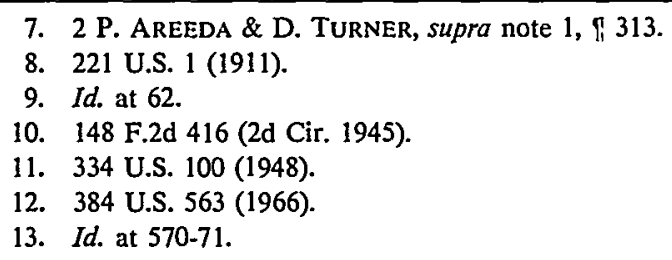


the "as distinguished from growth" language that follows makes clear that monopoly power is not unlawful unless accompanied by some impropriety.

The courts are likely to continue requiring proof that monopolists have engaged in impropriety until new legislation explicitly calls for a more regulatory approach.

\section{Identifying Impropriety}

It is easier to state the principles that should guide the definition of impropriety than to apply them. Grinnell gives us a negative definition: No impropriety is associated with "historic accident," a "superior product," or other manifestations of "business acumen." ${ }^{14}$ The last phrase may seem overly broad, but Aspen Skiing Co. v. Aspen Highlands Skiing Corp. ${ }^{15}$ recently made clear that there was no impropriety in "taking advantage of scale economies by constructing a large and efficient factory," 16 by achieving economic "efficiency," or by acting for "valid business reasons." 17 What is improper is "anticompetitive," "exclusionary," or "predatory" behavior, ${ }^{18}$ conduct that "has impaired competition in an unnecessarily restrictive way;" 19 or "attempting to exclude rivals on some basis other than efficiency."20

Although not self-defining, these words suggest that conduct is improper when it: (1) tends to inhibit the competitive vitality of rivals (or perhaps "abuses" monopoly power); (2) does not promote the "legitimate business purposes" or "competition on the merits" that the antitrust laws are designed to encourage; (3) can be identified in practice by antitrust courts; and (4) can be controlled without unduly chilling legitimate activity.

Though building a better mousetrap ruins rivals and brings monopoly power to the innovator, it constitutes the "business acumen" or "legitimate" activity that antitrust law wishes to promote. Though permanent pricing at the competitive level inhibits the entry of less efficient rivals who might become efficient with experience, competitive pricing is hardly objectionable. Though monopoly pricing "abuses" consumers, it neither obstructs rivalry nor inhibits entry by others, and is not amenable to control by antitrust courts unless they are to become price control agencies, a role they have long abjured.

\footnotetext{
14. See id.

15. 105 S. Ct. 2847 (1985).

16. Id. at 2854 (quoting jury instruction with approval, although the issue was not appealed).

17. Id. at $2858-59$.

18. Id. at 2857 .

19. Id. at 2859 (quoting 3 P. AREEDA \& D. TURNER, supra note 1, at 78).

20. Id. at 2859 (quoting R. BORK, THE ANTITRUST PARADOX 138 (1978)).
} 
These propositions and examples are reasonably clear and enduring, but other applications are not, as two illustrations readily show.

\section{Intention and the Problem of Assessing Conduct}

Intention is used in monopolization cases in several different ways. The first and most intelligible use is to illuminate the defendant's conduct. The defendant's stated purpose can often point the tribunal's analysis in the correct direction: toward a determination of whether that purpose is legitimate in principle and, if so, whether the challenged conduct is reasonably necessary to serve that purpose. Intention may also help to classify otherwise ambiguous behavior.

But even these accepted uses of intention can ultimately mislead courts and juries. First, the intention of a particular person, especially one in a low-level position, may not be that of "the firm." In addition, intentions are often unknowable or ambiguous. An expression of a procompetitive intention to prevail in the marketplace often sounds much like an expression of an anticompetitive predatory purpose. For example, the sales manager may have said, "Let's smash the new entrant," and this may sound like a "smoking gun" even though it was made in the course of a discussion about developing a better product. Thus, evidence of intention is often extremely prejudicial because the language of businessmen in the heat of competitive battle may sound predatory in the legal calm of the courtroom. The only intention that may be expressed is the defendant's legitimate desire to increase his sales and profits, but some courts nonetheless regard such expressions as suspicious or even illegitimate. ${ }^{21}$

This brings us to the second use of intention, not as one element in analyzing whether challenged conduct is anticompetitive, but rather as an independent basis for making such a characterization without reference to the conduct itself. This is a poor surrogate for a full competitive analysis, especially in the hands of a jury. The Supreme Court's Aspen decision is an unhappy example of how courts sometimes hold that a monopolist's conduct is anticompetitive solely on the basis of a finding of exclusionary intent on the part of that monopolist. ${ }^{22}$

Aspen involved the abandonment of a joint marketing agreement by a monopolist. Aspen Skiing Company dropped its participation in a multi-day lift ticket package that skiers could redeem at any of its three areas or at that of plaintiff Highlands. Multi-day packages offer skiers a discount from the usual daily rate. Because Aspen Skiing continued to

21. See 3 P. Areeda \& D. Turner, supra note 1, Iा 821-830; cf. Aspen, 105 S. Ct. 2847 (1985). \& g.

22. For a fuil discussion of Aspen, see P. AREEDA \& H. HovenKAMP, supra note 2, ig $736.1 \mathrm{f}$ 
market its own discounted multi-day, multi-area package, the Court could have found that it had employed a form of quasi-exclusive dealing-using monopoly power to create a price structure at its three areas that rewarded skiers for not skiing at Highlands.

Without focusing on this aspect of the monopolist's conduct, the Aspen Court approved jury instructions stating that monopolization had occurred if the jury found that the defendant acquired, maintained, or used its monopoly power for "anticompetitive or exclusionary purposes." 23 Apparently, a jury could conclude that a refusal to deal evidenced exclusionary intent, an intent relevant to characterizing the conduct as anticompetitive. ${ }^{24}$

The jury instruction approved by the Aspen Court could be used to condemn almost any act of a monopolist. Suppose that a monopolist: (1) refuses to license his patent, (2) opposes a would-be rival's licensing by a regulatory agency, (3) refuses to supply independent dealers with its product, (4) refuses to predisclose the results of his research and development, or (5) refuses to allow would-be rivals to utilize unused capacity at his mine, plant warehouse, dock, or refinery. Although the monopolist is under no absolute duty to do any of these things, might the Aspen Court allow a jury to find an anticompetitive or exclusionary intent on the part of the monopolist who does not? Obviously, these activities are exclusionary in the lay sense that such a monopolist intends to retain as much of the market as possible, just as the defendant did in Aspen. Futhermore, one might say, as the Aspen Court did, that many of these monopolists-such as the one who does not lease unused space in his warehouse to a competitor-sacrifice short-run revenue.

Yet Aspen does not clearly require that such conduct be left to the jury, for these examples do not involve Aspen's change in long-standing arrangements or its quasi-exclusive dealing feature. In addition, political action or the refusal to license a patent may be absolutely privileged. Moreover, the hypothetical defendants cannot be forced to deal unless the price is specified, and the general rule is that a monopolist does not violate the Sherman Act by charging a monopoly price. And even Aspen validates the refusal to deal based on legitimate business purposes. Importantly, many claimed justifications are based not on a judgment of the particular defendant's conduct, but on a more generalized estimate of social utility. For example, it is the fear of generally chilling the incentives for research that dissuades the courts from requiring a monopolist

23. Aspen. $105 \mathrm{~S}$. Ct. at 2854.

24. See id. at 2857 (distinguishing exclusionary refusals to deal from those protected by businessman's right to choose customers and associates). 
to disclose the fruits of his research to his rivals. ${ }^{25}$

The monopolist's intent to keep as much of the market as he can for himself is not the kind of exclusionary intent that automatically converts ordinary and useful behavior into unlawful monopolization. Nor is every important or distinctive resource of a monopolist an "essential facility" that must be shared. The major infirmity of the broad language of the jury instruction in Aspen is that it leaves to the jury unstated policy decisions as to privileged resources and legitimate business purposes.

Because there is nothing in the Aspen opinion to indicate that the Court considered these problems or meant to resolve them, I do not take that case to announce an enduring approach. Nevertheless, courts' general willingness to leave policy decisions of this sort to the jury on the basis of vague and general instructions displays one aspect of the law of monopolization that can interfere with efficient operation of business enterprises and that, by creating enormous uncertainty, burdens a firm and the legal system with unnecessary costs.

\section{E. Predatory Pricing and the Problem of Administrability}

Predatory pricing cases illustrate a very different trend. Until the last decade, predatory pricing clains were usually left to juries that had been instructed vaguely to look for "exclusionary" or "predatory" intent. More recently, courts have attempted to define predatory pricing in terms of its economic prerequisites and characteristics. Courts and the Federal Trade Commission have increasingly recognized, moreover, that some firms will, if they can, use the antitrust laws to chill legitimate price competition, which it is the law's purpose to encourage. Great care is therefore necessary, lest the law be misused to discourage rather than promote competition.

To be predatory, it is generally agreed that a price must be below the short-run profit maximizing level and must discipline or destroy rivals such that the predator thereafter gains sustained excess (that is, monopoly) profits far larger than those lost during the rival-bashing period. The uncertain future gains must greatly exceed the present actual losses to overcoine the uncertainty that rivals will be destroyed or disciplined and that monopoly profits can be reaped in the face of future entry. ${ }^{26}$ If rivals survive or entry occurs, not only will predation be unsuccessful, but that very prospect reduces the likelihood that a challenged low price is in fact predatory. Whenever the market circumstances make such predation unlikely, it is probably absent. In practical terms, this ineans that the search for predation can be abandoned when the alleged predator

25. See, e.g., Berkey Photo, Inc. v. Eastman Kodak Co., 603 F.2d 263, 281-84 (2d Cir.), cert. denied, 444 U.S. 1093 (1979).

26. Predators also face the risk of legal sanctions. 
lacks sufficient capacity to flood the market with enough product to depress the price below its rivals' costs or when subsequent entry is obviously easy. In these circumstances, there is little reason to test the alleged predator's prices against its costs.

Where the market circumstances make predation a possibility, courts have turned increasingly to objective price-cost comparisons to judge whether prices are predatory. For present purposes, it is enough to say that most courts regard prices above full cost as presumptively, if not categorically, lawful ${ }^{27}$ and prices above variable costs-a surrogate for marginal costs in at least some circumstances-as presumptively lawful. ${ }^{28}$ Both commentators and courts recognize that no cost-based presumptions can identify every price that is too low in the sense that a higher price might maximize the defendant's short-run profits or improve long-run consumer welfare. ${ }^{29}$ The critical question for legal policy is whether some other approach is likely both to maximize consumer welfare and to be effectively administrable by antitrust tribunals.

The courts have not attempted, nor are they equipped, to follow the economists who would have them evaluate whether a challenged price promotes long-run consumer welfare by determining, among other things, whether the defendant's capacity exceeds the minimum efficient scale of operation; and if so, whether it thereby precludes other producers from operating at minimum efficient scale; and if so, whether prices would be lower and output greater in the long run were the defendant's prices higher than they are, regardless of how high they are now. ${ }^{30}$ There is a consensus, even among critics of price-cost rules, that this individualized economic assessment is not practical, and it has not been taken up in the cases.

27. See, e.g., Arthur E. Langenderfer, Inc. v. S.E. Johnson Co., 729 F.2d 1050 (6th Cir.), cert. denied, 469 U.S. 1036 (1984); Barry Wright Corp. v. ITT Grinnel Corp., 724 F.2d 227 (Ist Cir. 1983); MCI Communications Corp. v. American Tel. \& Tel. Co., 708 F.2d 1081 (7th Cir.), cert. denied, 464 U.S. 891 (1983); Northeastern Tel. Co. v. American Tel. \& Tel. Co., 651 F.2d 76 (2d Cir. 1981), cert. denied, 455 U.S. 943 (1982); see also Southern Pac. Communications Co. v. American Tel. \& Tel. Co., 740 F.2d 980, 1055 (D.C. Cir. 1984) (conclusive legality of prices above average cost "relatively uncontroversial").

28. This rule can be inferred from cases holding that plaintiff failed to meet its burden of proof because it had not shown defendant's price to be below average costs. See, e.g., Airweld, Inc. v. Airco, Inc., 742 F.2d 1184 (9th Cir. 1984), cert. denied, 469 U.S. 1213 (1985); Adjusters Replace-A. Car, Inc. v. Agency Rent-A-Car, Inc., 735 F.2d 884 (5th Cir. 1984), cert. denied, 469 U.S. 1160 (1985); Sunshine Books, Ltd. v. Temple Univ., 697 F.2d 90 (3d Cir. 1982); California Computer Prods., Inc. v. IBM, 613 F.2d 727 (9th Cir. 1979); International Air Indus., Inc. v. American Excelsior Co., 517 F.2d 714 (5th Cir. 1975), cert. denied, 424 U.S. 943 (1976); Jay Foods, Inc. v. Frito-Lay, Inc., 614 F. Supp. 1073 (N.D. Ill. 1985); General Foods, 103 F.T.C. 204 (1984).

29. See generally P. Areeda \& H. HovenKamp, supra note 2, $\Uparrow 714.1$.

30. See Joskow \& Klevorick, A Framework for Analyzing Predatory Pricing Policy, 89 YALE L.J. 213 (1979) (arguing that the social cost of failing to identify predatory pricing is higher than finding predation where it does not exist). See generally P. AREEDA \& H. HOVENKAMP, supro note 2, II $714.2 \& 714.6$. 
Nevertheless, many courts have reserved the possibility that a price above variable cost or even above full cost might be predatory when it fails to maximize short-run profit and especially when entry barriers are high.

Although sacrifice of short-run profits is a necessary condition for the existence of predation, not every such sacrifice is predatory. A firm might charge less than it could get away with in the short run to forestall government price ceilings, to discourage long-run substitution of other products, or to expand the market. ${ }^{31}$ Similarly, antitrust policy should not abhor the more or less permanently maintained limit price-a strategic decision to reap less than the market will now bear, foregoing the higher profits that would attract new entrants. ${ }^{32}$ As I argue more fully in my Treatise supplement, ${ }^{33}$ limit pricing is difficult if not impossible to separate from market development pricing, while its presumed evils are at best speculative.

Fearful that some predation might slip through a cost-based formula, some courts have remained receptive to other factors. In Chillicothe Sand \& Gravel Co. v. Martin Marietta Corp. ${ }^{34}$ the Seventh Circuit stated:

while we accept the use of marginal or average variable cost as both a relevant and an extremely useful factor in determining the presence of predatory conduct, we are willing to consider the presence of other factors in our evaluation of whether or not [the plaintiff] has made out a prima facie case ....35

Even so, noncost factors are seldom potent enough to condemn a price above the relevant costs. The same court later said, in MCI Communications Corp. v. $A T \& T$, "We do not intend to imply that in all cases and in all circumstances we would only examine the price-cost relationship of a product or service." 37 Nevertheless, the court went on to say "that a judge or jury may not infer predatory intent unless price is below" the relevant cost measure, ${ }^{38}$ and "a strong presumption of lawfulness must attach when price ... [exceeds such costs]."39 The court simply reserved the possibility that "blockbuster" evidence might someday indicate predation regardless of cost level.

Similarly, other courts have also reserved the possibility that a plain-

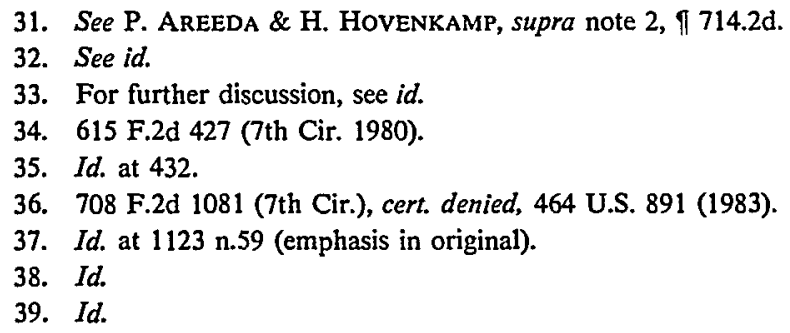


tiff might prevail by showing that a defendant "is charging a price below its short-run profit-maximizing price and barriers to entry are great enough to enable the [defendant] to reap the benefits of predation before new entry is possible." ${ }^{\prime 40}$ Still, as the Second Circuit has emphasized, the effort to formulate perfect predation rules may cause more harm than good. $^{41}$

The Ninth Circuit declared in William Inglis \& Sons Baking Co. $v$. ITT Continental Baking Co. ${ }^{42}$ that prices above average variable cost were presumptively lawful, but that this presumption could be overcome if the plaintiff proved that the challenged price did not maximize shortrun profits, but rather "that the anticipated benefits of defendant's price depended on its tendency to discipline or eliminate competition and thereby enhance the firm's long-term ability to reap the benefits of monopoly power." ${ }^{43}$ The Ninth Circuit thus supplemented a cost-based test with the vague formula just quoted. In Transamerica Computer Co. v. IBM, ${ }^{44}$ the same court held that the same test applied even if the challenged price were above full cost, except that the plaintiff in such a case would have to show the stated tendency by "clear and convincing evidence." 45 In any event, that court has not considered how this test would be applied, especially to the permanent limit price, whose benefit to the defendant does depend on its ability to exclude rivals.

The First Circuit rejected this inquiry in a perceptive opinion by Judge Breyer in Barry Wright Corp. v. ITT Grinnell Corp. ${ }^{46}$ The court first rejected the search for intent, because '“intent to harm' without more offers too vague a standard in a world where executives may think no further than 'Let's get more business,' and long-term effects on consumers depend in large measure on competitors' responses." ${ }^{\prime 47}$ The court acknowledged "the absence of any perfect touchstone," but judged marginal cost to be the best approximation. ${ }^{48}$

When prices exceed incremental costs, one cannot argue that they must rise for the firm to stay in business. Nor will such prices have a tendency to exclude or eliminate equally efficient competitors. Moreover, a price

40. International Air Indus., Inc. v. American Excelsior Co., 517 F.2d 714, 724 (5th Cir. 1975), cert. denied, 424 U.S. 943 (1976); see also Janich Bros., Inc. v. American Distilling Co., 570 F.2d 848, 856-57 (9th Cir. 1977), cert. denied, 439 U.S. 829 (1978); Hanson v. Shell Oil Co., 541 F.2d 1352, 1358 (9th Cir. 1976), cert. denied, 429 U.S. 1074 (1977).

41. Northeastern Tel. Co. v. American Tel. \& Tel. Co., 651 F.2d 76, 88-89 n.15 (2d Cir. 1981), cert. denied, 455 U.S. 943 (1982).

42. 668 F.2d 1014 (9th Cir. 1981), cert. denied, 459 U.S. 825 (1982).

43. Id. at 1035 .

44. 698 F.2d 1377 (9th Cir.), cert. denied, 464 U.S. 955 (1983).

45. Id. at 1388.

46. 724 F.2d 227 (1st Cir. 1983).

47. Id. at 232 .

48. Id. 
cut that leaves prices above incremental costs was probably moving prices in the 'right' direction-towards the competitive norm. ${ }^{49}$

Although acknowledging some utility in the Ninth Circuit test, the First Circuit rejected it because price cuts to levels above cost, especially above total cost, almost certainly move prices in a competitive direction, because such a "beneficial bird in the hand" is preferable to the "speculative bird in the bush" of lower future prices, and because the test is vague. ${ }^{50}$ To forbid limit pricing or every instance of a firm deciding not to raise its prices "risks making of the antitrust laws a powerful force for price increases."51 Moreover,

the general troubles surrounding proof of firm costs ... only hint at the difficulty of deciding whether or not a firm's price cut is profit-maximizing in the short-run, a determination that hinges not only on cost data, but also on elasticity of demand, competitors' responses to price shifts, and changes in unit costs with variations in production volume. ${ }^{52}$

Finally, the court emphasized that

the consequence of a mistake here is not simply to force a firm to forego legitimate business activity it wishes to pursue; rather, it is to penalize a procompetitive price cut, perhaps the most desirable activity (from an antitrust perspective) that can take place in a concentrated industry where prices typically exceed cost. ${ }^{53}$

The First and Second Circuits have both recognized that any pricecost test will not catch all instances of prices that injure rivals without benefiting consumers. "Nonetheless," according to the First Circuit, while technical economic discussion helps to inform the antitrust laws, those laws cannot precisely replicate the economists' (sometimes conflicting) views. For, unlike economics, law is an administrative system the effects of which depend upon the content of rules and precedents only as they are applied by judges and juries in courts and by lawyers advising their clients. Rules that seek to embody every economic complexity and qualification may well, through the vagaries of administration, prove counter-productive, undercutting the very economic ends they seek to serve. ${ }^{54}$

A critical issue thus presented by the predatory pricing debate is the tension between clarity and comprehensiveness. Although judges have been receptive to relatively clear rules of per se illegality, sometimes (though less so after Broadcast Music, Inc. v. Columbia Broadcasting System, Inc. ${ }^{55}$ ) condemning arrangements that they admit might be benefi-

\footnotetext{
49. Id. (emphasis in original).

50. Id. at 234 .

51. Id.

52. Id. at $234-35$.

53. Id. at 235

54. Id. at 234 .

55. 441 U.S. 1 (1979).
} 
cial in particular circumstances, they have been much less receptive to relatively clear standards that excuse arrangements that might be harmful in some circumstances, even when the harmful circumstances are rare or difficult to identify. ${ }^{56}$ This tension between relative certainty and "justice" in the particular case pervades all law, not just antitrust, and it will not be resolved uniquely within the antitrust arena. I believe that there are cyclical patterns here, and recent decades have seemed to denigrate considerations of clarity and administrability. As one court put it, in the context of vertical restraints, we cannot deny a plaintiff his "legal right" merely to serve the convenience of judges. ${ }^{57}$ However, relative clarity is itself an attribute of justice, allowing private parties to plan their affairs, minimizing the social burdens of uncertainty and the costs of litigation, and reducing the likelihood of quixotic results flowing from vague standards, inconsistently applied.

Still, what has occurred in the predatory pricing area is salutary. Courts have replaced entirely vague intention-based standards with more objective cost-based standards. Notwithstanding continuing controversy about which costs are most relevant, the interaction of economists, legal commentators, and judges has brought clarity to and engendered a substantial consensus on the prima facie tests for predation, albeit reserving the possibility of finding predation even though price exceeds some measure of costs. So long as these reservations are triggered only by relatively clear proofs, the prima facie rules will control most cases, and that is a giant step forward. The content of these presumptions will change with increased knowledge among economists and increased refinement in the legal scholars' incorporation of the lessons of economics, but the key point remains that this search for presumptions, even if not for absolute rules, will continue, not only in the predatory pricing area but throughout antitrust law.

II

\section{ATTEMPTED MONOPOLIZATION}

To the extent that antitrust law reaches improper unilateral conduct at all, it does so less through the doctrine of monopolization (for monopoly power is rare) than through doctrines of conspiracy and attempted monopolization. Although not part of my topic today, some exertions of

56. For a further discussion of judicial consideration of the long-term problems of predatory pricing, see P. AREEDA \& H. HOVENKAMP, supra note 2, ๆ 714.6.

57. Byars v. Bluff City News Co., 609 F.2d 843, 864 n.57 (6th Cir. 1979) (administrative difficulty in compelling vertical dealings without judicial determination of its terms insufficient ground for denying plaintiff's right); see also Chillicothe Sand \& Gravel Co. v. Martin Marietta Corp., 615 F.2d 427, 432 (7th Cir. 1980) (unacceptable to rely exclusively on variable cost price floor merely for judicial administrative convenience where destruction of equally efficient competitors might result). 
unilateral power-such as a supplier's refusal to sell his product to would-be customers who purchase the same or other goods from a rival supplier-are often addressed under Sherman Act section $1^{58}$ by characterizing compliant customers as acting in agreement with the supplier. In addition, improper behavior by potential monopolists constitutes attempted monopolization.

\section{A. The Doctrine and its Rationale}

The defendant who attains monopoly power with the aid of an impropriety violates the rule against improperly achieving or maintaining monopoly power. Hence, attempted monopolization has a distinctive role only where the challenged conduct has not generated a monopoly. ${ }^{59}$

Attempted monopolization cases do not closely match the underlying concept. The challenge for the future is to improve that match. The rationale for the offense is the desire to arrest or to punish conduct that, if continued, would lead to monopoly power. The classic formulation defines an attempt as conduct undertaken with an intention to bring about monopoly coupled with a dangerous probability of success. ${ }^{60}$ An attempt would thus be present if the initial market position of the defendant and the challenged conduct enhancing that position were such that monopoly power would likely result were that conduct to continue.

Unfortunately, we lack refined measures of both power and conduct. Not only do we lave great difficulty in saying more than that power is "substantial" or "slight," but we usually are unable to quantify the exclusionary degree of improper behavior. It is hard enough to decide that certain conduct tends to impair competition unjustifiably; our analytical tools seldom permit us to quantify the adverse effect enough to know whether and how much it will enhance the defendant's market position. Inevitably, therefore, courts have relied upon cruder tests, finding that improprieties by a defendant with a "substantial" market position are attempts to monopolize.

Unfortunately, both impropriety and substantial market position have been defined so loosely-leaving so much policy discretion to vaguely instructed juries-as to generate inconsistent results, foster uncertainty about outcomes, and threaten to transform Sherman Act section 2 into a federal prohibition of business torts.

58. 15 U.S.C. $\$ 1$ (1982) (prohibiting agreements in restraint of trade).

59. Even then, a defendant that does not possess monopoly power but is engaged in a course of conduct that appears likely to achieve it could be enjoined without needing to label its conduct an attempt. Nevertheless, legal interpretation has not followed this route.

60. Swift \& Co. v. United States, 196 U.S. 375, 396 (1905). 


\section{B. Conduct and Intent}

The conduct and intent elements of attempted monopolization have not been analyzed carefully by the courts. Unlike actual monopolization, the attempt offense requires a specific intent to monopolize. This may seem curious, because unjustified conduct reinforcing a substantial firm's market power in a way that creates a danger of monopoly implicates the statutory purpose regardless of the defendant's state of mind. To be sure, the generic criminal attempt requires specific intent, but attempted monopolization differs in two respects. First, unlike most crimes, the completed offense of monopolization requires no criminal intent. Second, the conduct constituting attempted monopolization is itself anticompetitive and contrary to the statutory purpose (when enough power is present), unlike the otherwise innocent acts constituting most ordinary criminal attempts. Nevertheless, the requirement of specific intent seems to have been carried over, at least verbally, from the criminal law. Of course, intention may illuminate ambiguous conduct, but much challenged conduct can be adjudged pro- or anticompetitive without reference to the actor's state of mind.

In practice, moreover, the specific intent requirement has served as a substitute for the analysis of conduct. In some instances, courts allow juries to premise liability on the defendant's intention to prevail in the marketplace-an intention indistinguishable from a motivation to compete. ${ }^{61}$ In other instances, courts allow juries to absolve defendants by finding a "legitimate business purpose." In both instances, the tribunal focuses on the defendant's state of mind rather than on the objective characteristics of the challenged behavior in its market context. For example, one court thought that a producer of tomato sauce could be guilty of attempted monopolization for imitating a rival's "thick and zesty" sauce. ${ }^{62}$ In this and many other cases, it would be better for the court to focus directly on the conduct. Doing so would reveal that imitation is generally privileged. The same would be true in the many cases in which one stockbroker challenges the hiring of his employee by a competitor. ${ }^{63}$

The failure to analyze conduct that I mentioned earlier in connection with the Aspen case is even more characteristic of the attempt cases. Even when intent is used in a manner favorable to the defendant-inviting the jury to find no specific intent to monopolize when the defendant intended to achieve a legitimate purpose-the jury speculates about the

61. See 3 P. AREedA \& D. TuRner, supra note 1, If 821-830.

62. See Hunt-Wesson Foods, Inc. v. Ragu Foods, Inc., 627 F.2d 919, 927 (9th Cir. 1980), cert. denied, 450 U.S. 921 (1981).

63. See, e.g., L.A. Draper \& Son v. Wheelabrator-Frye, Inc., 735 F.2d 414 (11th Cir. 1984); Stifel, Nicolaus \& Co. v. Dain, Kalman \& Quail, Inc., 578 F.2d 1256 (8th Cir. 1978). 
defendant's soul. It would be far better for the court to analyze the conduct, focusing on its anticompetitive tendencies in the light of its redeeming virtues. This would lead to more consistent rulings from case to case.

\section{Dangerous Probability of Monopoly}

Once a court thinks that it sees unjustified conduct and evil intent, it may fail to relate the defendant's misbehavior to the statutory concept and find attempted monopolization notwithstanding the absence of any reasonable prospect that monopoly power lies in store. To be sure, it might simplify administration of section 2 to dispense with proof of power when the challenged conduct (1) totally lacks any plausible claim to redeeming virtue, (2) is not likely to be rationally undertaken by a firm without a substantial degree of durable market power or its prospect, and (3) tends substantially to exclude competition in most cases. ${ }^{64}$ But courts have not done so, or at least have not done so openly.

Instead, some courts define unreasonably narrow markets in which the defendant has a large share, and the Ninth Circuit sometimes dispenses with proof of market position altogether, inferring a dangerous probability of monopoly from the defendant's specific intent to monopolize. ${ }^{65}$ Rather than demanding satisfaction of the three qualifications stated above, a court may define the defendant's own brand of a product as the relevant market and find that the defendant attempted to monopolize it by not selling to a would-be dealer or retailer. ${ }^{66}$ Some of the Ninth Circuit cases have found it sufficient that a refiner sought to tie his tire sales to the gasoline sales made to his dealers and thereby to "monopolize" his dealers' tire purchases. ${ }^{67}$ It should be obvious that such an intent or suclı a "market" lias nothing to do witlı monopoly power or its prospect.

I occasionally see a ray of hope wlien, for example, a panel of that circuit insists that the intention tliat can substitute for proof of a substan-

64. See 3 P. AREedA \& D. TURNER, supra note 1, |f 836.

65. See, e.g., Lessig v. Tidewater Oil Co., 327 F.2d 459 (9th Cir.), cert. denied, 377 U.S. 993 (1964) (first in a series of Ninth Circuit cases holding intent sufficient to infer dangerous probability); see also Mesirow v. Pepperidge Farm, Inc., 703 F.2d 339 (9th Cir.), cert. denied, 464 U.S. 820 (1983); Forro Precision, Inc. v. IBM, 673 F.2d 1045, 1058-59 (9th Cir. 1982); Gough v. Rossmoor Corp., 585 F.2d 381 (9th Cir. 1978), cert. denied, 440 U.S. 936 (1979); Knutson v. Daily Review, Inc., 548 F.2d 795, 814 (9th Cir. 1976), cert. denied, 433 U.S. 910 (1977). For further discussion of Ninth Circuit decisions in this area, see P. AREedA \& H. HovenkamP, supra note 2, 1832.1 .

66. See Blanton v. Mobil Oil Corp., 721 F.2d 1207 (9th Cir. 1983), cert. denied, 471 U.S. 1007 (1985) (rather than jury's finding that defendant had attempted to monopolize "Mobil-branded and non-Mobil-branded oil, lubricants, and tires, batteries, and accessories" sold to Mobil dealers, the court responded simply that market definition was not necessary in proving attempt).

67. Mobil Oil Corp. v. Blanton, 471 U.S. 1007, 1007-09 (1985) (Stevens, J., dissenting) (providing a recent criticism of the series of inferences generated by Lessig), denying cert. to Bianton v. Mobil Oil Corp., 721 F.2d 1207 (9th Cir. 1983). 
tial market position must truly be an intention to control a relevant market, or that conduct from which such an intention might be inferred must be truly and wholly exclusionary. ${ }^{68}$ But that hope then dims when another panel of that circuit returns to its prior ways. ${ }^{69}$

One innovation that deserves approval is the cumulation of several firms' collective market share to find a dangerous probability of monopolization in certain circumstances. United States v. American Airlines, Inc. ${ }^{70}$ is illustrative. The president of Braniff Airlines had received, recorded, and refused an offer from the president of American Airlines, Braniff's main competitor in the Dallas-Fort Worth area, to end their price war and raise fares twenty percent.

Sherman Act section 1 did not apply because no price-fixing agreement was consummated, and neither antitrust law nor federal criminal law prohibits attempts to form illegal conspiracies. As for section 2, American's individual market share was deemed too small to create a dangerous probability that it would gain a monopoly. Nevertheless, the Fifth Circuit feared that a failure to attach liability for solicitation of price-fixing conspiracies would serve as a "strong incentive to propose the formation of cartels. If the proposal is accepted, monopoly power is achieved; if the proposal is declined, no antitrust liability attaches."71

The court found its solution in Sherman Act section 2 and the analogous law of criminal attempt, holding that "the offense of joint monopolization would have been complete" at the moment Braniff accepted American's solicitation. ${ }^{72}$ The court held that probability of success should be measured "at the time the acts occur." American's offer was the "act that was the most proximate to the commission of the completed offense that [it] was capable of committing," the court found a dangerous probability that its planned conspiracy would succeed. ${ }^{74}$

We see [American]'s alleged conduct as uniquely unequivocal and its potential, given the alleged market conditions, as being uniquely consequential. In sum, our decision that the government has stated a claim

68. See Hunt-Wesson Foods, Inc. v. Ragu Foods, Inc., 627 F.2d 919, 925 (9th Cir. 1980), cert. denied, 450 U.S. 921 (1981).

69. See Northrop Corp. v. McDonnell Douglas Corp., 705 F.2d 1030, 1057 (9th Cir. 1983) (breach of contract by a dominant firm can constitute attempted monopolization).

70. 743 F.2d 1114 (5th Cir. 1984), cert. dismissed, 106 S. Ct. 420 (1985).

71. American Airlines, 743 F.2d at 1122.

72. Id. at 1118 .

73. Id. (citing Multiflex, Inc. v. Samuel Moore \& Co., 709 F.2d 980 (5th Cir. 1983) (attempt found in the exclusionary conduct of dominant firm even though market share was declining when conduct occurred), cert. denied, 465 U.S. 1100 (1984)).

74. Id. at 1118-19. See also id. at 1121 (distinguishing rejections of solicitation from criminal attempts: "an agreement to the solicitation would not result in the completion of the substantive offense at the moment of agreement; other physical acts were required for the completed offense"). 
does not add attempt to violations of Section 1 of the Sherman Act or lower the incipiency gate of Section $2 .^{75}$

The Fifth Circuit correctly perceived that where one firm seeks to organize a market into a de facto cartel with the aid of threats or other improper conduct, the probability that monopoly will result depends both on the defendant's behavior and on the cumulative market position of the would-be collaborators. ${ }^{76}$

\section{III MERGERS}

Antitrust law has vacillated in its approach to mergers. During the first quarter of this century, the courts routinely prevented mergers among major competing railroads without any close analysis of the degree of their competitive overlap or of the degree of remaining competition. ${ }^{77}$ In other segments of the economy, however, courts were strangely reluctant to interfere ${ }^{78}$ until Clayton Act section 7 was amended in $1950 .^{79}$ That amendment had two features. It extended the coverage of section 7 from just stock acquisitions to asset acquisitions as well, and it made clear that all mergers-vertical and conglomerate as well as horizontal-were prohibited when they tended substantially to lessen competition. More important, the 1950 amendment reflected, or was thought to reflect, ${ }^{80}$ an intensified hostility to mergers, although it did not alter the statutory criterion of illegality: the tendency substantially to lessen competition.

Impelled by that apparent change in the statutory mood, the Supreme Court embarked upon a relentless condemnation of mergers during the 1960's and early 1970's-often with little analysis of whether competition was likely to be impaired. One exasperated Justice finally

75. Id. at 1119.

76. Another example of an attempted conspiracy that a court was unable to fit within the law of attempted monopolization is United States v. Empire Gas Corp., 537 F.2d 296 (8th Cir. 1976), cert. denied, 429 U.S. 1122 (1977) (Empire threatened drastic price cuts if competitiors refused to raise prices, fix profits, and divide up the market; the Court found no dangerous probability of success because Empire did not hold a dominant position in the market, and its threats and subsequent price cuts did not induce competitor collusion).

77. See, e.g., Northern Sec. Co. v. United States, 193 U.S. 197 (1904), and United States v. Union Pac. R.R., 226 U.S. 61 (1912) (pre-Clayton Act cases); United States v. Reading Co., 253 U.S. 26 (1920) and United States v. Southern Pac. Co., 259 U.S. 214 (1922) (enforcing the Clayton Act).

78. See, e.g., Thatcher Mfg. Co. v. FTC, 272 U.S. 554 (1926) (holding that Clayton Act applies only to acquisitions of stock, not to acquisitions of assets); United States v. United States Steel Corp., 251 U.S. 417 (1920) (Sherman Act); United States v. Columbia Steel Co., 334 U.S. 495 (1948) (same).

79. The Celler-Kefauver Amendments, H. Res. 2734, 81st. Cong., 1st Sess., 95 Cong. REc. 11,484 (1950).

80. See, e.g., Brown Shoe Co. v. United States, 370 U.S. 294 (1962) (tracing the legislative history of Celler-Kefauver). 
observed that the only consistency in the brethren's merger decisions was that the governmental plaintiff always won. ${ }^{81}$ The worst excesses of that period-phony market definitions, mistaking increased efficiency for anticompetitive effect, and loose reasoning about potential anticompetitive effects-have passed, in part because of the decline of antimerger cases brought by the government and in part because of greater judicial sophistication.

There has always been a substantial consensus that the primary purpose of antimerger law is to block those mergers that threaten either to bestow market power on the merging firms or, by increasing concentration, to facilitate anticompetitive price coordination among oligopolists. Most enforcement efforts have addressed the oligopoly danger, with dispute centering inevitably on the following four questions:

\section{Do We Wish to Prevent Only Those Mergers Threatening to Create Oligopoly or Also Those Reinforcing Existing Anticompetitive Pricing?}

The clear answer is: Both. Indeed, the question would hardly arise except that the Department of Justice's Merger Guidelines regard any grouping of products or areas as too small to be a "relevant market" if a "small but significant and non-transitory price increase"-usually five percent for one year-would not be profitable in view of buyer shifts to other products or areas. ${ }^{82}$ Such a test would broaden the market too far and thus understate a merger's significance whenever the existing price level was already supracompetitive. The Department justified this approach on the ground that section 7 was designed to catch only those mergers that newly create a danger of oligopoly pricing and not to catch those mergers that reinforce preexisting anticompetitive pricing. The Department's position on this is wrong, will not be fully accepted by courts, and thus is not viable.

\section{Should Intervention Be Deferred Until We Are Reasonably Certain That Anticompetitive Price Coordination Will Occur?}

Because we are able to do so little to prevent the anticompetitive operation of existing oligopolies, the policy of section 7 is prophylactic and designed to prevent oligopoly from arising or surviving. Obviously, the question remains: How prophylactic? Different answers to this question, whether or not addressed directly, account for the disparities about to be discussed.

81. United States v. Von's Grocery Co., 384 U.S. 270, 301 (1966) (Stewart, J., dissenting).

82. Merger Guidelines, supra note 5 , at 26,828 . 


\section{What Degree of Concentration Threatens Oligopoly?}

There is no concentration number above which anticompetitive pricing is clearly threatened and below which competition is clearly assured. The concentration numbers thought anticompetitive by the Supreme Court cases of the 1960 's seem unduly low today. ${ }^{83}$ Although those numbers incorporated im the Justice Department's Merger Guidelines may seem very high, some theorists regard the danger of oligopoly as much overblown, doubting that higher profits generally are associated with higher concentration.

It is hard to say which position is more viable here. With less consensus that oligopoly is harmful and with no certainty about the right concentration numbers, all I can hazard to predict is that enforcement authorities and courts will and should ultimately settle toward the more prohibitive side of the academic dispute, for the statute's prophylactic purpose means, I believe, that we should be cautious in accepting the view that even significant concentration withm a market is not harmful.

\section{Should a Prima Facie Illegal Merger Be Tolerated (a) When One}

of the Parties Is Less Competitively Significant Than Its Market Share Suggests or Is a Failing Company, (b) When Entry Barriers Are Modest, or (c) When Efficiencies Are Created?

Bypassing the peculiarities of a merging firm or its possible failure, I will comment briefly on entry barriers and efficiencies in mergers and their interrelationships.

Mergers can but do not necessarily increase efficiencies. I think the day has passed when assumed cost savings are used to condemn a merger, and I would expect efficiencies to absolve mergers, even those that exceed whatever numerical measures of prima facie illegality may be adopted. I will not pause to specify which potential efficiencies miglit be considered or liow they should be proved, but only to consider whether some arbitrary level of cost savings-such as five percent of total costshould be an absolute defense, perhaps even to a monopoly-creating merger, or only a factor to be weighed against the danger associated witlı a particular increase in concentration. ${ }^{84}$

One answer seems clear: Significant efficiencies should be an absolute defense to those mergers that barely offend the numerical threshold of prima facie illegality or to those that occur in markets with very low barriers to entry, and this seems especially appropriate as the prima facie

83. See Von's, 384 U.S. at 302 n.35 (Stewart, J., dissenting) (combined shares of two largest firms increased from $14.4 \%$ to $15.5 \%$; of six largest firms, from $32.1 \%$ to $35.4 \%$ ); United States v. Pabst Brewing Co., 384 U.S. 546 (1966) (postmerger market share only 4.49\%).

84. For further discussion see P. AREEDA \& H. HovenkaMP, supra note 2, ๆ 901. 
standard is more prophylactically prohibitive. The answer is more elusive at the other end of the spectrum. Consider the rare case in which a merger would unite the only two firms in an undoubtedly significant market and would undoubtedly reduce production costs by five percent. The position of consumers would be improved if the monopoly price at the lower-cost level would be less than the premerger (competitive? duopoly?) price, but we can say little more than that lower prices and higher output are more likely as the cost savings are greater.

Notwithstanding the postulated cost savings, however, monopoly might worsen output, price, and resource allocation. Still, if those savings are undoubted, and if a market-wide firm is necessary to achieve them, one of the two firms is likely to take over the market in order to realize those cost savings, with some considerable waste in the process of squeezing out the less efficient firm. In that event, preventing the monopoly will not preserve the second firm; it will only waste resources. Given the assumption of undoubted proof that the merger generates substantial efficiencies that cannot be attained in any less restrictive way, it seems prudent to tolerate the merger, especially when we will seldom know the price-output effects with any precision. International competition has driven home the importance of not obstructing increased productivity in domestic markets.

The role of entry barriers in merger analysis has become quite troublesome. It is true that permanent supracompetitive pricing is not possible when entry barriers are trivial. On the other hand, the loss to competition resulting from a merger is a present fact, while the new entry that might overcome that detriment is speculative. The prophylactic purpose of section 7 should make us hesitate to give up the bird in the hand (present competition) in the hope that a bird in the bush (future entry) will make up for that loss. The prospect of new entry is not a perfect substitute for the loss of present competition and can seldom be judged very precisely.

Nevertheless, there are three possible reasons for giving weight to the relative modesty of entry barriers. First, there would be no anticompetitive effect when entry is patently easy and quick. Second, attention to the prospect of new entry corrects unduly narrow market definitions. Third, mergers may involve important efficiencies that cannot be proved as such and that will be lost if the law prevents mergers-a needless loss when future entry will prevent any substantial harm to the economy in the long run. The first reason is weighty and suggests that patently easy entry should defeat prima facie illegality. The second calls for better market definition.

The third reason explains the hospitality of some commentators and enforcement agencies to substantial horizontal mergers. Those who 
believe that horizontal mergers are motivated mainly by the prospect of unprovable efficiencies prefer a hospitable rather than a prophylactic approach. I tend to believe that such a hospitable approach will not be continued, at least given the present statute and the present state of our knowledge about horizontal mergers.

\section{IV}

\section{Market Power Assessments}

The weakest and least viable aspect of antitrust law's dealing with market structure-monopohization, attempted monopolization, and mergers-lies in its assessment of market power and its definition of markets. However sensible the substantive legal standards governing monopolies and mergers might be, they lead to senseless results unless markets and market power are correctly determined. Wise assessment is impaired because (1) the law fails to specify the degree of power that should concern us in any particular case, (2) the difficulties of assessing power directly have impelled courts to rely instead on the defendant's share of a "market," (3) the data bearing on market definition is usually incoinplete and is often obscured by experts functioning as advocates, (4) many tribunals have confused the legal issue by assuming that a "market" and a "submarket" could simultaneously be relevant to the appraisal of a particular transaction, (5) even when correctly measured, inarket share is an imperfect surrogate for power, and (6) the issue is often left to juries on the basis of vague instructions. I will comment briefly on only a few of these difficulties.

Because we can seldom measure market power directly, we often infer it from the defendant's share of a relevant market. That market consists of those who supply or could readily supply the defendant's product or acceptable substitutes. Substitutes acceptable to buyers lie along a spectrum, similar products available nearby on one end, geographically distant and imperfect yet possibly sufficient products on the other. It is possible to describe the entire spectrum as a "market" and the increasingly narrower groupings as "submarkets," but this double labeling is superfluous and distracts attention from the real question: What is the market relevant to the theory of antitrust violation being pursued?

The confusion that the "market" and "submarket" language can introduce into the antitrust inquiry is illustrated in the lower court's opinion in the Aspen case. ${ }^{85}$ There, the Tenth Circuit approved the following jury instruction:

85. Aspen Highlands Skiing Corp. v. Aspen Skiing Co., 738 F.2d 1509 (10th Cir. 1984), aff'd on other grounds, 105 S. Ct. 2847 (1985). The Supreme Court did not consider the market definition issue. 
There can be both a relevant market and a relevant sub-market or just a relevant market without any relevant submarket. Thus, if you decide that the relevant product market is downhill skiing at destination ski resorts, you must still determine whether downhill skiing services in Aspen, including multi-area, multi-day lift tickets is a sub-market within the larger market. ${ }^{86}$

Thus instructed, the jury found that the market was downhill skiing at North American destination ski resorts and that the submarket was downhill skiing at Aspen. This ignores the critical issue: Which market did defendant need to control in order to be able to successfully charge monopoly prices? The legal issue before the court controls what the relevant market is. If the charge is monopolization, the relevant market is that spectrum of products acceptable to consumers seeking to substitute rather than pay a monopoly price. If the defendant possesses a large enough share of that market to be able to raise prices at will, the defendant possesses monopoly power. Similar analysis flows from merger cases, where the issue is whether the shift in concentration provides a new company the market share position to control price unilaterally or through actual or tacit agreement with remaining competitors. The Tenth Circuit thus committed a clear but not rare error in allowing the jury to find power in a submarket while failing to foreclose the possibility that skiers confronted with monopoly prices at Aspen Mountain might be equally satisfied with less expensive vacations at Vail or Lake Tahoe.

Perhaps courts fall into this error because they fail to think about the degree of pricing discretion that should conceru the law. Suppose, for example, that we somehow learn with astonishing precision that a firm dominating skiing in Aspen could raise prices one percent without repelling any significant number of consumers, while a two-percent increase would repel so many that it would be unprofitable. A court confronted with these facts might well be uncertain whether the onepercent pricing discretion should be enough to make Aspen a market relevant to the legal purpose of judging the existence of monopoly power. Without any clear instruction from the statute or principle as to the significance of one percent in this case, a court may understandably direct its focus to either a larger "market" or a smaller "submarket." But such a usage must be recognized for what it is-an evasion of the tribunal's responsibility to decide the policy question of what degree of potential power over price suffices to demarcate a market relevant to the particular legal question before the court.

I would like to think that these submarket confusions are not viable, though they are unfortunately embedded in the cases.

86. Id. at 1528. For a more thorough discussion of the Aspen instruction, see P. AREEDA \& H. HoVENKaMP, supra note 2, ๆ 518.b. 


\section{CONCLUSION}

Even this brief tour of monopolization, mergers, and markets reveals the extraordinarily clear dependence of antitrust law on economic policy, economic theory, and empirical investigation, mainly by economists. We might think such "economicization" of the law to be a new wave and a future portent, ominous for some and blessed for others. But even an occasional examination of the older cases reveals an awareness of policy, theory, and empiricism. To take only two examples, the early railroad cartel cases were not insensitive to the possibilities of destructive marginal-cost pricing, ${ }^{87}$ and the 1916 American Can case ${ }^{88}$ seems very modern in its tone.

What has changed in recent years is the dissipation of the mid-century consensus on what serves sound economic policy and the statute, the burial of some old shibboleths, and the creation of some new ones. But that is surely to be expected when neither the world nor our understanding of it stands still. The weakness of the common law approach to antitrust is its uncertainty; its strength is its adaptability and thus survivability. That is why the Sherman Act is likely to last for another century.

87. See, e.g., United States v. Trans-Missouri Freight Ass'n, 166 U.S. 290 (1897); United States v. Joint Traffic Ass'n, 171 U.S. 505 (1898).

88. United States v. American Can Co., 230 F. 859 (D. Md. 1916), appeal dismissed, 256 U.S. 706 (1921). 
